\title{
En koptisk homili og anmeldelse af tre doktordisputatser
}

Den første artikel i dette nummer rummer Jesper Tang Nielsens indledning og oversættelse af en fragmentarisk koptisk tekst, der blev opdaget på det ægyptiske museum i Berlin i 1990'erne og opfattet som et evangelieskrift. Man daterede den til det 2. årh. og gav den det moderne navn Gospel of the Savior. Den seneste forskning har imidlertid påvist, at der findes fragmenter af den samme tekst i to andre håndskrifter, og man mener nu, at der snarere er tale om en homili fra det 5.-6. årh., som man kalder Apocryphon Berolinensel Argentoratense. Nielsen, der fordansker denne titel som Berlinerapo$k r y f e n$, redegør for den seneste udvikling i forskningen og bringer den første danske oversættelse af den samlede tekstoverlevering, forsynet med oplysende noter.

Dernæst følger tre anmeldelsesartikler af teologiske doktordisputatser; de udspringer alle af forfatternes opposition ved de tre forsvarshandlinger.

Svend Andersen anmelder Ulrik B. Nissens afhandling om Bonhoeffers etik inden for den lutherske tradition. Nissen finder både en universalistisk og en partikularistisk dimension i den lutherske etik, der imidlertid er tæt forbundne i kraft af den chalkedonensiske kristologis begreb om communicatio idiomatum. Andersen er enig i, at luthersk etik rummer disse to dimensioner, men stiller spørgsmål ved, om den klassiske kristologi er relevant i denne sammenhæng.

Tine Reeh anmelder Kurt E. Larsens afhandling om Christian Bartholdy. Larsen har undersøgt et stort og uudforsket kildemateriale, som han imidlertid ikke analyserer fra en kronologisk synsvinkel. Reeh betvivler værdien af denne metode, idet hun hovedsageligt opfatter Bartholdy som en ikke-systematisk og kontekstuelt bestemt teolog. Reeh fremlægger i øvrigt en række interessante udtalelser fra Bartholdys side vedrørende forholdet mellem luthersk teologi og det indremissionske begreb om "omvendelsen", ligesom hun fremdrager et nyt kildemateriale fra Bartholdys tidlige ungdom, der kaster et interessant lys på hans personlighed.

Anders Klostergaard Petersen anmelder Anders-Christian Jacobsens afhandling om Origenes' kristologi og soteriologi. Jacobsen søger en enhed bag Origenes' mangfoldige udtryk, bl.a. gennem den tese, at mangfoldigheden skyldes, at Origenes henvendte sig til forskellige målgrupper. Petersen stiller imidlertid spørgsmål til afhandlingens teori og metode, samt peger på, at tesen ikke er et egentligt nybrud. 